\title{
Role of ABAS and Bureaucratic Reformation in Improving Governmental Financial Performance Through Financial Decision Making
}

\author{
Muhammad Arief AFFANDI ${ }^{1}$, Etty MURWANINGSARI $^{2}$, Sekar MAYANGSARI ${ }^{3}$, Susi DWIMULYANI ${ }^{4}$
}

Received: August 01, 2020 Revised: October 05, 2020 Accepted: October 15, 2020

\begin{abstract}
This research is aimed at examining the effect of the implementation of ABAS and BR on GFP with FDM as mediation. Respondent of research is 100 civil servants at the Directorate General of Population and Civil Registration of the Ministry of Home Affairs for the Republic of Indonesia. Data analysis is done with WarpPLS. Result of research shows that the implementation of ABAS has direct and indirect effects on GFP, and the indirect effect involves the mediation of FDM. Other result indicate that the making of proper financial decisions will help improving GFP. The effectiveness of financial decisions are able to mediate the implementation of ABAS in improve GFP. Meanwhile, BR does not affect GFP, either directly or indirectly through FDM. BR seems oriented more toward improving public service and people's welfare. This research suggests that the next research should examine whether the implementation of BR can improve governmental organizational performance in delivering public service. This research has proven that the implementation of ABAS has helped in improving the quality of FDM, while the other benefit is that this system improves GFP. Moreover, this research also gives confirmation that accounting information in good quality will be very useful in FDM.
\end{abstract}

Keywords: Accrual-Based Accounting, Bureaucratic Reformation, Good Governance, Financial Decision Making, Governmental Financial Performance

JEL Classification Code: G28, H11, H19

\section{Introduction}

The last few decades showed that many states, including Indonesia, had reformed its governmental skeletons in the financial field. There is a strong demand for having transparent and accountable financial management, and such

${ }^{1}$ First Author and Corresponding Author. PhD Student, Faculty of Economic and Business, Trisakti University, Indonesia [Postal Address: Jl. Kyai Tapa No.1, RT.6/RW.16, Grogol, Kec. Grogol petamburan, Kota Jakarta Barat, Daerah Khusus Ibukota Jakarta 11440, Indonesia] Email: affandiarief5@gmail.com

${ }^{2}$ Lecturer, Faculty of Economic and Business, Trisakti University, Indonesia. Email: etty_nasser@yahoo.com

${ }^{3}$ Lecturer, Faculty of $\bar{E}$ conomic and Business, Trisakti University, Indonesia. Email: sekar_mayangsari@trisakti.ac.id

${ }^{4}$ Lecturer, Faculty of Economic and Business, Trisakti University, Indonesia. Email: susi.dwimulyani@trisakti.ac.id

(c) Copyright: The Author(s)

This is an Open Access article distributed under the terms of the Creative Commons Attribution Non-Commercial License (https://creativecommons.org/licenses/by-nc/4.0/) which permits unrestricted non-commercial use, distribution, and reproduction in any medium, provided the original work is properly cited. demand can only be satisfied with the presence of accounting system that is not only fulfilling the conditions of legality and validity, but is also able to provide useful and precise information for the users, at least allowing users to judge the issues and make decisions in more rational and logical ways to achieve accountability goal (Hookana, 2008). Financial reformation in Indonesia is marked by the implementation of ABAS on public sector's financial statements, including financial statements made by central and local government agencies (Nguyen, 2020). Information produced by ABAS are considered more beneficial than cash-based standards because accrual information is able to give accurate description about financing and fund procurement services. Accrual-based accounting information is considered more able to improve government accountability (Carlin, 2005). Besides this, accrual-based accounting infomation can also help the users to improve financial management, to produce more precise comparison of financial performance among entities, and to stabilize governmental policies (Chirani \& Amin, 2016). The implementation of accrual-based governmental accounting standards that refers to Government Regulation No.71/2010 is aimed at creating high-quality financial information and 
more accurate performance measurement. This arrangement should surely enable the government to make decisions effectively regarding governmental financial management to improve GFP and also financial service delivered by the government (Badriyah, 2011).

Some empirical researches generally had found that the implementation of ABAS in governmental context has given benefits and has positive implication to the improvement of GFP. Nogueira and Jorge (2013) found that the implementation of accrual-based accounting standards in Portugal has enabled the users to complete the internal decision making process. Salleh et al. (2014) discovered that ABAS can effectively support outcome-based budgeting systems used by the government, and has been successful in providing relevant data related to costs and expenses. Moreover, Najati et al. (2016) declared that information obtained from ABAS are more comprehensive and more reflective than the actual condition, which is surely useful for the decision makers. It can be said that the implementation of ABAS will improve reporting quality and financial performance. In general, previous researches show that financial decisions that can precisely and effectively strengthen governmental accountability and improve GFP are mostly derived from information given by ABAS (Paulsson, 2006; Nogueiraa and Jorgeb, 2012; Agriyanto et al., 2016). In this matter, there is one stage that must be passed through by financial statements that are drafted by ABAS, and this stage is the execution of FDM. BR is a factor that can help in creating accountability, improving public service performance, and ensuring the realization of people welfare (Ria et al., 2016). BR is aimed to develop a bureaucracy that is clean, efficient, effective and productive in delivering public service. BR is designed to create transparent and accountable bureaucracy in serving the people (Kasim, 2013). BR helps the government to build capacity to enhance public service scope, to establish bureaucracy that is professional, clean, accountable, neutral and effective, which can serve the people properly, and also to create the so called democratic governance management to achieve better GFP (Labolo \& Indrayani, 2017; Gaus et al., 2016).

It needs to be understood that research on the effect of the implementation of ABAS on GFP through the mediation of FDM is rarely conducted within the Indonesian context. Therefore, the current research has contributed to the solving of poor accounting systems in Indonesia. The originality of this research is on the use of FDM as a mediation/intervening variable in the effect of the implementation of ABAS and $\mathrm{BR}$ on GFP. Information derived from ABAS are considered more accurate and comprehensive, and therefore, these information should be used in FDM in order to improve financial management, to produce more precise comparisons of financial performance among entities, and to stabilize governmental policies (Chirani \& Amin, 2016).
Some results are obtained from the current research. Each result is explained as follows. The implementation of ABAS has a positive effect on GFP, but BR does not affect GFP. The implementation of ABAS has a positive effect on FDM, but BR does not affect FDM. Furthermore, FDM has positive effect on GFP. In case of indirect effect, GFP mediates the effect of the implementation of ABAS on GFP. The contribution of the current research is providing guidance for the implementation of good governance at the Work Unit for Demographic and Civil Registration under auspices the Ministry of Domestic Affairs for the Republic of Indonesia.

\section{Literature Review}

\subsection{The Effect of The Implementation of ABAS on GFP}

There are three theories used in this paper, namely new public management (NPM) theory, institutional theory (Modugu \& Dempere, 2020, Rahman, et al., 2020), and decision usefulness theory. The effect of the implementation of ABAS on GFP is explained with institutional theory. The Indonesian Government has planned reformation in the accounting field by issuing Government Regulation No.71/2010 on Governmental Accounting Standards that require every governmental institution to implement ABAS. If a governmental institution does implement ABAS, then it complies with institutional theory, which says that an organization will adjust itself to the environment by creating a social reality as an order consisting of rules and standard behaviors. Self-adjustment done by organizations or institutions is underlaid by shared conception to achieve a success (Lundmark, 2008; DiMaggio \& Powell, 2000). The implementation of ABAS in the public sector is a governmental effort to produce transparent and accountable financial statements. ABAS has been proved to be able to improve financial performance accountability of governmental institutions, especially in delivering information about goals, functions, and objects of expenses (Pamungkas, 2012; Newcomer, 2007; Nogueira \& Jorge, 2013; Chirani \& Amin, 2016; Najati et al., 2016). Another research (Kober et al., 2010) added that ABAS can improve accountability and therefore, should be used by government officers in a public sector environment. All the findings above, in general, show that the implementation of ABAS has a positive effect on financial performance. If the governmental accounting system is complying with the Accrual-Based Governmental Accounting Standards, then GFP will be better and more accountable. Based on that statement, first hypothesis is written as following: GFP. 


\subsection{The Effect of $B R$ on GFP}

Bureaucratic reformation process in governmental environments is greatly influenced by the ideology of New Public Management (Osborne \& Gaebler, 1992). As a theory, New Public Management (NPM) is a new concept of governmental management that applies private sector's work practices to the public sector in order not only to improve efficiency and effectiveness of governmental performance but also to achieve public welfare. The formula of BR is focused on reforming governmental roles in designing and organizing governmental works and its apparatus at local, regional and national levels through decentralization process or agencification model (Gaus et. al, 2016). An organization will always adjust itself to the environment by establishing organizational structure that facilitates itself in achieving success. It conforms to institutional theory, which explains that organizational structure is always influenced by the social environment where the organization exists (Carruthers, 1995). Governmental BR is aimed to develop a bureaucracy that is clean, efficient, effective, and productive. Indeed, BR is designed to create a transparent and accountable bureaucracy in serving public interest (Kasim, 2013). Moreover, Hajar (2015) declared that BR allows the government to build capacity to enhance public service scope, to establish bureaucracy that is professional, clean, accountable, neutral and effective, which can serve public interest, and also to create democratic governance management to achieve better GFP (Labolo \& Indrayani, 2017; Gaus et al., 2016). In regard of all the findings above, it can be said that BR has a positive effect on GFP. BR is a way to adopt private sector's managerial technique and practice to public sector. Based on this statement, second hypothesis is developed as following:

\section{$\boldsymbol{H}_{2}: B R$ has a positive effect on GFP.}

\subsection{The Implementation of ABAS on FDM}

Decision Usefulness Theory explains the conditions that an organization must fulfill if it wants to produce high-quality and useful accounting information that can guide users in making decisions. Accrual-based accounting information provided in financial statements must fulfill the conditions of transparency and accountability. If these conditions are met, then the government can use information in financial statements as the base in FDM. Nogueira (2013) found that ABAS is greatly useful for internal decision making (for financial, political and technical matters). This system facilitates the organization in processing information regarding budget content and disclosure. The important point from the implementation of ABAS is that information produced by this system are available and ready to be used for decision making, which enables the organization to be more transparent and accountable, and to assess the performance of public entities for the sake of public interest (Salam \& Sutaryo, 2019; Agriyanto et al., 2016). By virtue of all research findings above, it can be said that the implementation of ABAS has positive effect on FDM. ABAS enables the government in making decisions on various financial issues such as resource allocation, identification of costs for tangible and intangible products, management of assets and liability, and others. The implementation of ABAS can improve the quality of financial decisions, which at least will make the decisions become more logical and rational. Third hypothesis is declared as following:

\section{FDM. \\ $\boldsymbol{H}_{3}:$ The implementation of ABAS has positive effect on}

\subsection{The Effect of BR on FDM}

Governmental workers or officers in public service are acting like the igniter or the driver of the machine and they never bring in their personal interest in decision making (Gaus et al., 2016). If any of them give priority to their interest over others, then conflict of interests may occur and cause what is called information asymmetry. This situation is just like what has been explained in agency theory presented by Jensen and Meckling (1976), which indicates that the relationship between government and people (public) is like the relationship between principal and agent. People as principals make agreements with the government or agent. The agreement will implicitly and explicitly require agents to act in compliance with the interest of the principal. But, agent as the manager of the state always have more information than the principal, and consequently, there is always a risk of information asymmetry (Zimmerman, 1977). BR is a governmental effort to minimize information asymmetry. What the government does in this matter is by revitalizing the system and restructuring public service institutions. Problems of Indonesian bureaucracy are always on the humans and also the system that manages those humans, and therefore, the fast solution is through BR (Yusriadi, 2018). Delegating authority from people to government is the representation of agency relationship, and this will put the government under obligation to be accountable to the people for its performance, and one way to realize this accountability is by making financial decisions in more transparent and logical ways (Ria et al., 2016). After taking into account all the findings above, it can be said that BR has a positive effect on FDM. BR is also said as governmental revitalization that involves various activities such as restructuring public service institutions, simplifying public service procedures, and setting the standards for the use of information and communication 
technologies, especially in managing public complaints. In accord with these statement, fourth hypothesis is written as following:

\section{$\boldsymbol{H}_{4}:$ BR has a positive effect on FDM.}

\subsection{The Effect of FDM on GFP}

In agency theory, people as principals do not have access to all the information that the government as agent has. People find it difficult to supervise governmental action. To ensure that the government will produce good governance, an external audit on the public sector's financial statement is needed. This audit will function as "check and balance" to mitigate information asymmetry and to improve financial statements' transparency (Djanegara, 2017). Audit on public sector's financial statements is like an opportunity for auditors to make opinions based on adequate and accurate audit proofs in order to ensure that financial statements are free from material error. Financial statements that get reasonable audit opinion without exception (unmodified auditor's report) will be trusted by parliamentary members, legislative members, and other stakeholders, and is considered as true representation of public sector's financial performance (IASB, 2014). Empirical research has found that FDM has a positive effect on GFP. Financial decisions stated in high-quality financial statements can mitigate information asymmetry problems, and therefore, increase the efficiency and effectiveness of allocation and utilization of economic resources. If financial decisions are of high quality, then GFP will also be of high quality, especially when it involves reasonable audit results without exception, which helps the government to improve the credibility of its financial statements (Deloitte, 2015; Nogueira, 2013). Relative to this elaboration, fifth hypothesis is proposed as following:

\section{$\boldsymbol{H}_{5}: F D M$ has a positive effect on GFP.}

After examining Hypothesis 1, 2, 3, 4 and 5 as direct effect relationships, then hypothesis 6 and 7 are put forward to represent indirect effect relationships, which are stated as following:

$\boldsymbol{H}_{6}:$ The implementation of $A B A S$ has an indirect effect on GFP through the mediation of FDM.

$\boldsymbol{H}_{7}: B R$ has an indirect effect on GFP through the mediation of FDM.

\section{Research Method}

Population of research are 100 civil servants as respondents from the Directorate General of Population and Civil Registration of the Ministry of Home Affairs for the Republic of Indonesia. Sample of research technique used in this research is purposive sampling. Type of research data is primary data. Field study is conducted at a research location along with distributing questionnaires. Data analysis technique in this research is PLS-SEM, which is supported by WarpPLS 7.0. This technique is chosen because the nature of research is predictive and explanatory. This technique is chosen for two reasons. One of the reasons is that this technique can still work efficiently although the size of sample is small and the structure of the model is complex. The other reason is that the assumption of data distribution in PLS-SEM is relatively looser than the other methods, such as $\mathrm{CB}$ (Covariance-based)-SEM (Sholihin \& Ratmono, 2013). Hypothesis testing over hypothesis 1 to 7 is using model equation as following:

$$
\begin{aligned}
& \mathrm{GFP}=\alpha_{1}+\beta_{1} \mathrm{ABAS}+\beta_{2} \mathrm{BR}+\beta_{3} \mathrm{FDM}+\epsilon_{1} \\
& \mathrm{FDM} \quad=\alpha_{2}+\beta_{5} \mathrm{ABAS}+\beta_{6} \mathrm{BRI}+\epsilon_{2}
\end{aligned}
$$

\section{Results}

All respondents are working at the Work Unit for Demographic and Civil Registration under auspices of the Ministry of Domestic Affairs for the Republic of Indonesia. Totally, there are 100 respondents examined in this research. After using demographic criterion, male respondents are $63 \%$, whereas female respondents are $37 \%$. Age criterion is also used, which it is shown that respondents with age between $30-40$ years old is $51 \%$, whereas respondents with age of over 40 years old is $49 \%$. For the criterion of educational level, respondents with graduate degree are $47 \%$, whereas respondents with postgraduate degree are $53 \%$. The distribution of rank criterion is explained as follows: number of first-tier managing officers are $1 \%$, administrative officers are $28 \%$, supervisory officers are $67 \%$, and treasury officers are $4 \%$.

As shown in Table 1, the research model has good fit because $\mathrm{p}$-value for APC is $<0.05$, while for ARS and AAR is $<0.1$. Precisely, the value of APC is 0.186 , while the values of ARS and AARS are 0.102 and 0.79 . The values of AVIF and AFVIF are $<3.3$, which signifies that there is no multicollinearity problem across indicators and across exogenous variables. Goodness of fit has value of 0.233 , which is $\geq 0.1$, and based on this result, it can be said that model has very good fit. The values of SPR and RSCR are 1 respectively, while the value of SSR is 0.8 , which is precisely $>0.7$, and which denotes that the model does not have causality problems (Latan \& Ghozali, 2016). The estimation of inter-construct relationship and its variance and effect size are shown in table 2 . 
Table 1: Goodness of Fit of Structural Model

\begin{tabular}{|l|c|}
\hline Criteria & Parameter \\
\hline Average path coefficient (APC) & $0.186 / \mathrm{P}<0.05$ \\
\hline Average R-squared (ARS) & $0.102 / \mathrm{P}<0.1$ \\
\hline Average adjusted R-squared (AARS) & $0.079 / \mathrm{P}<0.1$ \\
\hline Average block VIF (AVIF) & 1.036 \\
\hline Average full collinearity VIF (AFVIF) & 1.051 \\
\hline Tenenhaus GoF (GoF) & 0.233 \\
\hline Sympson's paradox ratio (SPR) & 1.000 \\
\hline R-squared contribution ratio (RSCR) & 1 \\
\hline Statistical suppression ratio (SSR) & 0.8 \\
\hline
\end{tabular}

Table 2: Results of Inter-Construct Relationship Estimation

\begin{tabular}{|l|c|c|c|}
\hline Description Path & Path Coefficient & $\mathbf{R}^{2}$ & $\mathbf{Q}^{2}$ \\
\hline $\mathrm{ABAS} \rightarrow$ GFP & $0.205^{\star *}$ & 0.151 & 0.192 \\
\hline $\mathrm{BR} \rightarrow$ GFP & 0.124 & & \\
\hline $\mathrm{FDM} \rightarrow$ GFP & $0.342^{* * *}$ & & \\
\hline $\mathrm{ABAS} \rightarrow \mathrm{FDM}$ & $0.145^{*}$ & 0.007 & 0.038 \\
\hline $\mathrm{BR} \rightarrow$ FDM & 0.114 & & \\
\hline
\end{tabular}

${ }^{* * *},{ }^{* *},{ }^{*}$ denotes significance levels at $0.01,0.05$ and 0.1 , respectively.

In regard to the contents in Table 2 , the value of adjusted $\mathrm{R}$-squared $\left(\mathrm{R}^{2}\right)$ for the variation that affects GFP is 0.151 , which stands for that the effect of the variations of The Implementation of ABAS, BR, and FDM on the variation of GFP is $15.1 \%$, while the remaining $84.9 \%$ are affected by other variables in the research model. The variation that affects FDM is 0.007, which denotes that the effect of the variations of The Implementation of ABAS and BR on the variation of FDM is $0.7 \%$, while the remaining $99.3 \%$ are affected by other variables out of the research model. The value of adjusted $\mathrm{R}$-squared $\left(\mathrm{R}^{2}\right)$ for the variation that affects GFP and FDM is in weak category due to $\mathrm{R}^{2}<0.25$ (Latan $\&$ Ghozali, 2016). The value of $\mathrm{Q}-$ Squared $\left(\mathrm{Q}^{2}\right)$ produced by each endogenous variable, either GFP or FDM, is $>0$, which indicates that the model has predictive relevance (Latan \& Ghozali, 2016). Pertaining to the results of estimations of path coefficient and p-value, it is shown that the implementation of ABAS has a positive and significant effect on GFP. The resultant $\mathrm{p}$-value is $<0.05$, and the path coefficient value is 0.205 , which signifies that those results are supporting hypothesis 1 . These results also support previous researches, which generally showed that the implementation of ABAS has a positive effect on GFP (Nogueira \& Jorge, 2013; Chirani \& Amin, 2016; Najati et al., 2016). Moreover, those results are in line with institutional theory, which said that institutions or organizations do self-adjustment as the form of shared conception to achieve a success (Carruthers, 1995; DiMaggio \& Powell, 2000; Lundmark, 2008). The implementation of ABAS is an action to make adjustments to the relevant regulations (or to obey the existing rules) in order to obtain the benefits of accountability and also to improve GFP.

Next, hypothesis test was conducted on hypothesis 2 , and the result indicated that $\mathrm{BR}$ has a positive but not significant effect on GFP, with p-value of $>0.1$ and path coefficient value of 0.124 , which signifies that those results are rejecting hypothesis 2 . These results are not consistent with previous findings, which said that BR can improve GFP (Labolo \& Indrayani, 2017; Gaus et al., 2016). However, those results are supporting Ria et al. (2016) who discovered that BR does not have effect on financial performance but does greatly affect public service and people welfare. Indeed, BR is needed to improve organizational performance of the government to ensure that the government will deliver public service and people welfare. Furthermore, hypothesis 3 was also tested and the result revealed that the implementation of ABAS has positive and significant effect on FDM, with p-value of $<0.1$ and path coefficient value of 0.145 . These results confirm that hypothesis 3 is accepted, and support the findings of previous researches, which denote that ABAS facilitates FDM (Salam \& Sutaryo, 2019; Agriyanto et al., 2016). Those results are in consonance with decision usefulness theory, which explains that if accounting information are of good quality, then this information will be useful in FDM.

Hypothesis test was implemented on hypothesis 4, and the result showed that BR does not have significant effect on FDM, with p-value of $>0.1$ and path coefficient value of 0.114 . These results reject hypothesis 4 and surely are not in agreement with Ria et al. (2016) and Yusriadi (2018) who found that BR makes FDM become accountable. Results of hypothesis test on hypothesis 5 indicated that GFP has positive and significant effect on FDM, with a $p$-value of $<0.01$ and path coefficient value of 0.342 . These results confirm that hypothesis 5 is accepted, and therefore, support the findings of previous researches, which showed that making a proper financial decision will mitigate information asymmetry in financial reporting, and it can help improving financial performance (Deloitte, 2015; Nogueira, 2013).

The testing of hypothesis 6 and 7 will use a mediation test method. In this research, the method is Variance Accounted For (VAF). According to Hair et al. (2013), mediation test procedure with VAF method comprises of several steps that can be described as following: 1) it will test the direct effect of exogenous variable on endogenous variable without involving mediation variable, 2 ) if the direct effect is significant, then it continues with testing the indirect effect of exogenous variable on endogenous variable, but now with involving mediation variable, 3 ) if the indirect effect is 
significant, then it continues with counting VAF value and determining mediation effect with the following criteria: a) if the condition is VAF $>80 \%$, then it signifies that there is full mediation; $b$ ) if the condition is $20 \% \leq \mathrm{VAF} \leq 80 \%$, it denotes that there is partial mediation; c) if the condition is $\mathrm{VAF}<20 \%$, it indicates that there is no mediation effect in the model. The counting of VAF is done by dividing the indirect effect with the total effect (direct effect plus indirect effect). The direct effect of the implementation of ABAS and BR on GFP is presented in table 3.

Regarding to the contents of Table 3, it can be seen that the implementation of ABAS has direct and significant effect on GFP, with p-value of $<0.05$, whereas BR does not have direct and significant effect on GFP, with p-value of $>0.1$. Based on these results, it can be said that only ABAS is potentially mediated by FDM to give indirect effect on GFP. Meanwhile, it is also found that FDM does not mediate the indirect effect of BR on GFP. According to these findings, hypothesis 6 is accepted, whereas hypothesis 7 is rejected. Thereafter, because hypothesis 6 is accepted but hypothesis 7 is not, then the calculation of VAF value is only done for hypothesis 6, precisely on the indirect effect of ABAS on GFP through FDM. As already shown in table 4, the indirect effect of ABAS on GFP through FDM is significant, with a path coefficient value of $0.049(0.145 \times 0.342)$. The calculation of VAF value for this relationship is described in table 4 .

As indicated in Table 4, VAF value is 0.193 or $19.3 \%$, which is considered approaching $20 \%$. This signifies that FDM is a partial mediator to the indirect effect of ABAS on GFP. This result supports and also accepts hypothesis 6, which says that the effect of the implementation of ABAS on GFP is mediated by FDM. In other words, the improvement of GFP is not merely affected by the implementation of ABAS, but also involves the making of proper financial decisions underlaid by accounting information that is comprehensive and accurate.

Table 3: Direct Effect of ABAS and BR on GFP

\begin{tabular}{|l|c|c|}
\hline Description Path & Path Coefficient & P-value \\
\hline $\mathrm{ABAS} \rightarrow$ GFP & 0.205 & 0.016 \\
\hline $\mathrm{BR} \rightarrow$ GFP & 0.124 & 0.101 \\
\hline
\end{tabular}

Table 4: VAF Calculation for the Indirect Effect of ABAS on GFP through FDM Mediation

\begin{tabular}{|l|c|}
\hline Description & Path Coefficient \\
\hline Indirect effect & 0.205 \\
\hline Direct effect & 0.049 \\
\hline Total effect & 0.254 \\
\hline VAF (indirect effect/total effect) & 0.193 \\
\hline
\end{tabular}

\section{Conclusion}

Result of research shows that the implementation of ABAS has direct and indirect effects on GFP, and the indirect effect involves the mediation of FDM. Other results indicate that the making of proper financial decisions will help in improving GFP. The effectiveness of financial decisions is able to mediate the implementation of ABAS in improving GFP. Meanwhile, BR does not affect GFP, either directly or indirectly through FDM. BR seems oriented more toward improving public service and people welfare. This research suggests that the next research should examine whether the implementation of BR can improve governmental organizational performance in delivering public service. This research has proven that the implementation of ABAS has given at least two major benefits to the government. One of these is that ABAS helps improve the quality of FDM, while the other benefit is that this system improves GFP. Moreover, this research also gives confirmation that accounting information in good quality will be very useful in FDM.

\section{References}

Agriyanto, R., Rohman, A., Ratmono, D., \& Ghozali, I. (2016). Accrual Based Accounting Implementation: An Approach For Modelling Major Decisions. Risk Governance \& Control: Financial Markets \& Institutions, 6(4), 531-539.

Badriyah, S. N. L. (2011). Implementation of PP No. 71/2010 About Accrual Based SAP: Goals, Benefits, Constraints and Strategies. Ebbank Journal, 2(2), 225-230.

Carlin, T. M. (2005). Debating The Impact of Accrual Accounting and Reporting in The Public Sector. Financial Accountability \& Management, 21(3), 309-336.

Carruthers, B. G. (1995). Accounting, ambiguity, and the new institutionalism. Accounting, Organizations and Society, 20(4), 313-328.

Chirani, E., \& A. S. Amin. (2016). The role of full accrual basis of accounting to improve account. In: 2nd International Conference on Accounting, Management and Innovation in Business, Iran.

Deloitte. (2015). The Future is Now: Digital Financial Services in Indonesia. Deloitte Library Journal, 9(2), 201-2012.

DiMaggio, P. J., \& Powell, W. W. (1983). The iron cage revisited institutional isomorphism and collective rationality in organizational fields. American Sociological Review, 48(2), $147-160$

Djanegara, M. S. (2017). The Effect of Audit Quality on the Quality of Local Government Financial Reports. Accounting Journal, 21(3), 461.

Gaus, N., Sultan, S., \& Basri, M. (2016). State Bureaucracy in Indonesia and its Reforms: An Overview. International Journal of Public Administration, 40(8), 658-669. 
Hajar, B. (2015). Bureaucracy and Governance in Indonesia: Study on West Sulawesi Province. Procedia Economics and Finance, 23, 223-227.

Hair, J. F., Hult, G. T. M., Ringle, C. M., \& Sarstdett. M. (2013). A Primer on Partial Least Squares StructuralEquation Modeling (PLS-SEM). Los Angeles, CA: Sage Publications.

Hookana, H. (2008). Organisational Culture and the Adoption of New Public-Management Practices. Management, 3(4), 309-327.

Jensen, M. C. \& Meckling, W. H. (1976) Theory of the firm: Managerial behavior, agency costs and ownership structure. Journal of Financial Economics, 3(4), 305-360.

Kasim, A. (2013). Bureaucratic Reform and Dynamic Goernance for Combating Corruption: The Challenge for Indonesia. Business \& Bureaucracy Journal, 20(1), 18-22.

Kober, R., Lee, J., \& Ng, J. (2010). Mind Your Accruals: Perceived Usefulness Of Financial Information In The Australian Public Sector Under Different Accounting Systems. Financial Accountability \&Management, 26(3), 0267-4424.

Labolo, M., \& Indrayani, E. (2017). Bureaucratic Reform and the Challenge of Good Governance Implementation in Indonesia. Journal of Asian Review of Public Affairs and Policy, 2(4), 26-47.

Latan, H., \& Ghozali. I. (2016). Partial Least Square Concepts, Methods and Applications Using WarpPLS 5.0. Semarang, Indonesia: Diponegoro University Publishing Agency.

Lundmark, M. (2008). The defence industry integration. In: Conference: Nordic Workshop on Interorganizational Research., Bergen, Norway August 21-23, 2008.

Modugu, K. P., \& Dempere, J. (2020). Country-Level Governance Quality and Stock Market Performance of GCC Countries. Journal of Asian Finance, Economics and Business, 7(8), 185-195. https://doi.org/10.13106/jafeb.2020.vol7.no8.185

Najati, I., Pituringsih, E., \& Animah, I. (2016). Accrual-Based Accounting Implementation: Testing the Determinants and Implications for the Quality of Ministry / Institution Financial Reports. Journal of Accounting, University of Jember, 14(1), $1-18$.

Newcomer, K. E. (2007). Measuring Government Performance. International Journal of Public Administration, 30(3), 307-329.
Nguyen, T. K. T. (2020). Studying Factors Affecting Environmental Accounting Implementation in Mining Enterprises in Vietnam. Journal of Asian Finance, Economics and Business, 7(5), 131144. https://doi.org/10.13106/jafeb.2020.vol7.no5.131

Nogueira, S. P. S., \& S. M. F. Jorge. (2013). The usefulness of financial reporting for internal decision-making in Portuguese municipalities. Management Research: Journal of the Iberoamerican Academy of Management, 11(2), 178 - 212.

Nogueiraa, S. P., \& Jorgeb, S. M. (2012). Adequacy of the Local Government financial reporting model in the context of internal decision-making: An exploratory study in the municipality of Braganca. Review of Applied Management Studies, 10(2), 74-86.

Osborne, D., \& Gaebler, T. (1992). Reinventing Government. New York, NY: Ingrid Schneider. https://doi.org/10.1080/00222216 1995.11949751

Pamungkas, B. (2012). The effect of the application of public accounting and the quality of laws and regulations on the quality of financial reports and the performance accountability of government agencies. Ranggagading Scientific Journal of Accounting and Management, 12(1), 1-10.

Paulsson, G. (2006). Accrual Accounting In The Public Sector: Experiences From The Central Government In Sweden. Financial Accountability \& Management, 22(1), 267-424.

Rahman, M. M., Sobhan, M., \& Islam, S. (2020). The Impact of Intellectual Capital Disclosure on Firm Performance: Empirical Evidence From Pharmaceutical and Chemical Industry of Bangladesh. Journal of Asian Finance, Economics and Business, 7(2), 119-129. https://doi.org/10.13106/jafeb.2020. vol7.no2.119

Ria, M. D., Siregar, H., \& Bratakusumah, D. S. (2016). Analysis of the Influence of Bureaucratic Reform on Local Government Performance Case Study in West Java Provincial Government. Civil Service Journal, 10(1), 51 - 67.

Salleh, K. R., Aziz, A., \& Bakar, Y. N. A. (2014). Accrual accounting in government: Is fund accounting still relevant?. Procedia Social and Behavioral Sciences, 164, 172 - 179.

Salam, A., \& Sutaryo, S. (2019). The suitability of the Accrual Financial Reporting System in Internal Decision Making in Local Governments. Assets Journal of Accounting and Education, 8(1), 21-34. 